\title{
Adsorptive Removal of Zinc by Using Neem Powder and Saw
} Dust

M. Murali Naik ${ }^{1}$ and K. Aruna ${ }^{2 *}$

1. Chemical Engineering Department, JNTUACE, Anantapuramu, India-515002

2. Associate Professor, Department of Chemistry, Governament Degree College, Nagari- 517590

Mobile no : 9247262230

ABSTRACT
The work concerns the studies on batch adsorption of zinc from waste water using adsorbents such as Neem powder and saw dust. Neem leaves adsorbent developed from locally available tree leaves to assess suitability remediates zinc contaminated water. Factors affecting the adsorption characteristics such as contact time, adsorbent dosage, $\mathrm{pH}$ on zinc efficiency were studied and best values for maximum removal were found. It was observed that the percentage removal of zinc increases with increase in adsorbent dosage, reaches equilibrium value and also with increase in agitation time, removal percentage was increased. All the experiments were performed at room temperature and at a stirring rate of $120 \mathrm{rpm}$. The maximum removal was observed for neem powder compared with saw dust.

Keywords: natural adsorbents, saw dust, Neem, zinc, adsorption isotherm and waste wate

\section{INRODUCTION}

Mostly zinc enters the environment as a result of mining, zinc purification, burning of coal and wastes. It is found in almost 100 enzymes and protiens which plays major role in DNA replication. Its deficiency causes malfunctioning and disorders in metabolism and functioning of human organs. If large doses of zinc (10-15 times higher than the RDA) are taken by mouth even for a short time, stomach cramps, nausea, and vomiting may occur. Levels of zinc in excess of $500 \mathrm{ppm}$ in soil interfere with the ability of plants to absorb other essential metals, such as iron and manganese.

Hence due to its adverse effects on biological systems waste waters containing zinc have to be treated before releasing into the environment. The conventional methods used to remove chromium from aqueous include high capital and regeneration costs of the materials; these are not suitable for the small-scale industries. Therefore, there is currently a need for new, innovative and cost effective methods for the removal of toxic substances from wastewaters. Among these processes Adsorption with the selection of suitable adsorbent can be an effective and versatile method and can be easily adopted in low cost to remove heavy metals from large amount of industrial wastewaters.

The adsorbents are neem leaves powder and saw dust which generally has high metal adsorption capacity. A novel adsorbent was developed from mature leaves of natural Neem trees for removing toxic substances from water. The adsorbent, in the form of fine powder was found to be very effective in removing traces of zinc in waste waters.

\footnotetext{
*Coresponding Author: email: aruna7544@gmail.com
} 
The Neem tree (Azadirachtaindica) of family meliaceae is native to the Indian subcontinent and its seed sand leaves have been in use since ancient times to treat a number of human ailments and also as a house hold pesticide. Leaves of the tree are used as antiinflammatory, anxiolytic, anti-androgenic, anti-stress, humoral and cell-mediated immune stimulant, anti-hyperglycemic, liver-stimulant, anti-viral and anti-malarial activities. The aim of the present investigation is to detect the performance of neem leaves powder and saw dust on zinc removal from aqueous solutions by varying contact time, $\mathrm{pH}$ and adsorbent dosage .Langmuir and Freundlich isotherms were applied to fit the experimental data.

\section{MATERIALS AND METHODS ADSORBENT PREPARATION \\ Saw Dust}

The saw dust collected from local saw mill. Firstly the adsorbent washed and dried at room temperature to avoid the release of color by adsorbent in to the aqueous solution. The activation of adsorbents is carried out by treating it with concentrated sulphuric acid $0.1 \mathrm{~N}$ and is kept in an oven maintained at a temperature range of $20^{\circ} \mathrm{C}$ for 24 hours. Again is washed with distilled water to remove the free acid.

It has a variety of practical uses, including serving as mulch, or as an alternative to clay cat litter, or as a fuel, or for the manufacture of particleboard. It has also been used in artistic displays and as scatter.

\section{Neem}

The matured neem leaves are collected from neem trees. They are washed, dried and powdered. Then the fine particles are collected by sieving by 200 mesh. Then it is washed with hydrochloric acid and dried. Then again it is washed with distilled Water. Then it is dried at $20^{\circ} \mathrm{C}$ in an oven for 24 hours to activate and cool to room temperature. It is in fine powder form. The powder is in thick green colour which enhances the bio adsorption rate. The colour of this adsorbent adsorbs the traces of toxic substances effectively. The powdered neem is then soaked in hydrochloric acid for few hours. Then solution is filtered using whattman filter paper. After that it is dried again and washed with distilled water then it is filtered with whattman filter paper. It is dried and stored in moisture free container.

\section{Adsorbent Preparation}

The processed neem powder as mentioned earlier is sieved using 150-200 mesh. Undersize particles were collected.

A stock solution of zinc was prepared by dissolving $1 \mathrm{~g}$ of zinc in $1000 \mathrm{ml}$. this solution was diluted as required to obtain standard solutions containing $1000 \mathrm{mg} / \mathrm{l}$ of zinc.

\section{Preparation of Adsorbate solution}

A stock solution of zinc was prepared by dissolving of $1 \mathrm{~g}$ of zinc in $1000 \mathrm{ml}$. This solution was diluted as required to obtain standard solution containing $1000 \mathrm{mg} / \mathrm{l}$ of zinc.

\section{Batch adsorption experiments}

Batch adsorption experiments were conducted by agitating the standard flasks $(250 \mathrm{ml})$ at room temperature in a mechanical shaker. The effect of time and $\mathrm{pH}$ was studied with a zinc concentration of $1000 \mathrm{mg} / \mathrm{l}$ and an adsorbent dosage of $20 \mathrm{~g} / \mathrm{l}$ the aqueous solution $\mathrm{PH}$ was adjusted in the range of 1-14 by using dilute HCL and $\mathrm{NAOH}$ solutions. Experiments were carried out by varying the adsorbent amount 
from 20 to $100 \mathrm{~g}$ with a zinc concentration of $1000 \mathrm{mg} / \mathrm{l}$. Finally, Zinc concentrations were analyzed spectrophotometrically.

\section{Effect of agitation time}

The effect of agitation time on zinc removal was observed at zinc concentration of $1000 \mathrm{mg} / \mathrm{l}$ and adsorbent dosage of $20 \mathrm{~g}$. The adsorbent dosage of $1 \mathrm{~g}$ was added to the 10 different standard flasks containing $50 \mathrm{ml}$ of adsorbent solution concentration $1000 \mathrm{mg} / \mathrm{l}$. Flasks numbered $1,2,3 \ldots .$. , were placed in mechanical shaker at $120 \mathrm{rpm}$ for $30 \mathrm{~min}, 60 \mathrm{~min}, \ldots . .150 \mathrm{~min}$ respectively. Final zinc concentration in the adsorbate solution was found spectrophotometrically at $310 \mathrm{~nm}$. And percentage removal of zinc was calculated.

\section{Effect of Adsorbent dosage}

The effect of adsorbent dosage on zinc removal was observed at zinc concentration of $1000 \mathrm{mg} / \mathrm{l}$ at agitation time of $90 \mathrm{~min}$. The prepared adsorbate solution was diluted to $1000 \mathrm{mg} / \mathrm{l}$. Adsorbent solution was transferred into $100 \mathrm{ml}$ standard flasks. the adsorbent dosage of $1 \mathrm{~g}, 2 \mathrm{~g}, 3 \mathrm{~g}, 4 \mathrm{~g}$ and $5 \mathrm{~g}$ were added to the flasks numbered $1,2,3 \ldots$ respectively. Then the flasks were placed in a mechanical shaker at room temperature. The speed of the shaker is maintained at $120 \mathrm{rpm}$ and for a contact time of $90 \mathrm{~min}$. then the flasks were taken out and liquid in the flasks were filtered by what man filter paper. The filtered solution was analyzed in UV spectrophotometer at a wavelength of $310 \mathrm{~nm}$. The percentage removal of phenol was found using standard calibration chart

\section{Effect of pH}

effect $\mathrm{pH}$ on zinc removal is observed at zinc concentration of $1000 \mathrm{mg} / \mathrm{l}$ and at agitation time of $90 \mathrm{~min}$. The prepared adsorbate solution diluted to $1000 \mathrm{mg} / \mathrm{l}$ and $\mathrm{pH}$ of the solution was found using $\mathrm{PH}$ meter. Then the $\mathrm{pH}$ of the solution was made to $5,6,8,10,12$ by using $\mathrm{NaOH}$ and $\mathrm{HCl}$ of appropriate concentrations and solutions of different $\mathrm{pH}$ were taken in different flasks. Then the adsorbent made of $1 \mathrm{~g}$ was added to the above solutions. These standard flasks were placed in mechanical shaker for $90 \mathrm{~min}$. The speed of the shaker was maintained at 120rpm. After the completion of above mentioned agitation flasks were taken out and solutions were filtered using whatman filter paper. The filtered solution was analyzed using UV spectrophotometer at a wavelength of $310 \mathrm{~nm}$. Similarly the percentage removal of zinc was found using standard calibration.

The equilibrium amount of metal ion adsorbed per liter was calculated from the difference between the initial $\left(\mathrm{C}_{\mathrm{i}}\right)$ and final (equilibrium) concentration $\left(\mathrm{C}_{\mathrm{eq}}\right)$ in the solution. Respectively

$$
\mathrm{X}=\mathrm{C}_{\mathrm{i}}-\mathrm{C}_{\mathrm{eq}} \quad \mathrm{mg} / \mathrm{L}
$$

The adsorption percentage was calculated by using from the following equation:

$$
\text { Percentage of adsorption }=\left(\left(\mathrm{C}_{\mathrm{i}-} \mathrm{C}_{\mathrm{t}}\right) / \mathrm{C}_{\mathrm{i}}\right) \times 100
$$

Where, $\mathrm{C}_{\mathrm{i}}$ and $\mathrm{C}_{\mathrm{t}}$ are the initial and at time $(\mathrm{t})$ of the adsorbate concentration, respectively. The final concentration is determined by correlating adsorbance and concentration from standard calibration chart.

\section{RESULTS AND DISCUSSION}

All the experiments were carried out at a room temperature $305 \mathrm{k}$ and speed of the shaker was maintained at $120 \mathrm{rpm}$ and adsorbate solution of concentration $1000 \mathrm{ppm}$. 
Table:Comparison of percentage removal of zinc using different adsorbents

\begin{tabular}{|c|c|c|c|c|c|c|c|c|}
\hline \multirow{2}{*}{$\begin{array}{l}\text { Agitation } \\
\text { time } \\
\text { (min) }\end{array}$} & \multicolumn{2}{|c|}{$\begin{array}{l}\% \text { removal of } \\
\text { Zinc }\end{array}$} & \multirow{2}{*}{$\begin{array}{c}\text { Adsorbent } \\
\text { dosage } \\
(\mathrm{g} / \mathrm{l})\end{array}$} & \multicolumn{2}{|c|}{$\begin{array}{c}\% \text { Removal of } \\
\text { Zinc }\end{array}$} & \multirow[t]{2}{*}{$\mathrm{pH}$} & \multicolumn{2}{|c|}{$\begin{array}{c}\% \text { removal of } \\
\text { Zinc }\end{array}$} \\
\hline & Neem & $\begin{array}{l}\text { Saw } \\
\text { dust }\end{array}$ & & Neem & $\begin{array}{l}\text { Saw } \\
\text { dust }\end{array}$ & & Neem & $\begin{array}{l}\text { Saw } \\
\text { dust }\end{array}$ \\
\hline 30 & 45 & 33 & 1 & 65 & 63 & 4 & 61 & 65 \\
\hline 60 & 55 & 49 & 2 & 70 & 65 & 6 & 67 & 71 \\
\hline 90 & 72 & 56 & 3 & 72 & 70 & 8 & 72 & 78 \\
\hline 120 & 80 & 70 & 4 & 74 & 74 & 10 & 79 & 81 \\
\hline 150 & 83 & 75 & 5 & 82 & 77 & 12 & 77 & 79 \\
\hline
\end{tabular}

\section{Effect of agitation time}

The effect of agitation time on the adsorption of zinc using neem powder and Saw dust was studied at adsorbent dosage of $20 \mathrm{~g} / \mathrm{l}$.

The effect of agitation time using two adsorbents was compared in the graph as shown in Fig. 1. It is inferred that from the graph neem powder had shown better results. About $83.6 \%$ removal of zinc was reported for neem powder and the next best results were observed for saw dust (about $80 \%$ removal).

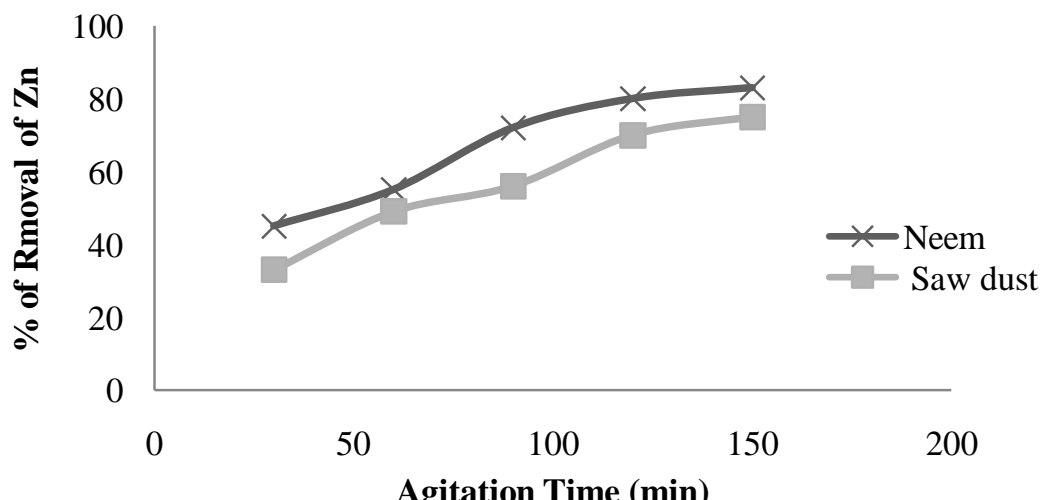

Fig.1 Effect of agitation time on \%removal of zinc using two adsorbents

\section{Effect of adsorbent dosage}

The effect of adsorbent dosage on the percentage removal of zinc was studied at $120 \mathrm{rpm}$ and agitation time of $90 \mathrm{~min}$ using neem powder and Saw dust the values are tabulated. From the graph shown in Fig. 2 it is observed that the best results were shown by neem powder and then saw dust.

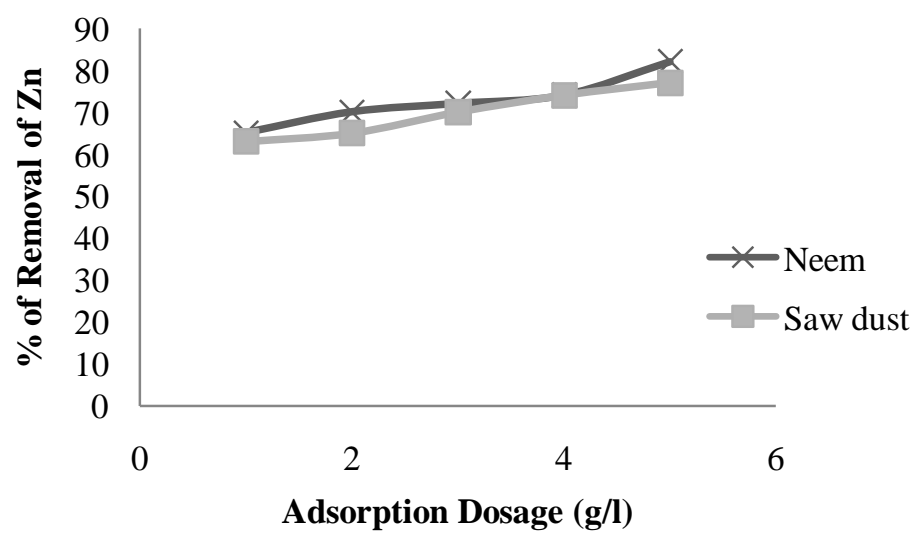

Fig.2 Effect of adsorbent dosage on \% removal of zinc using two adsorbents 


\section{Effect of pH}

Effect of solution $\mathrm{pH}$ on removal of zinc was studied using neem powder as adsorbent at adsorbent dosage of $20 \mathrm{~g} / \mathrm{l}$ and agitation time of $90 \mathrm{~min}$. the values are tabulated below in Table. $\mathrm{P}^{\mathrm{H}}$ of the solution is adjusted by using $\mathrm{HCl}$ and $\mathrm{NaOH}$ solutions.

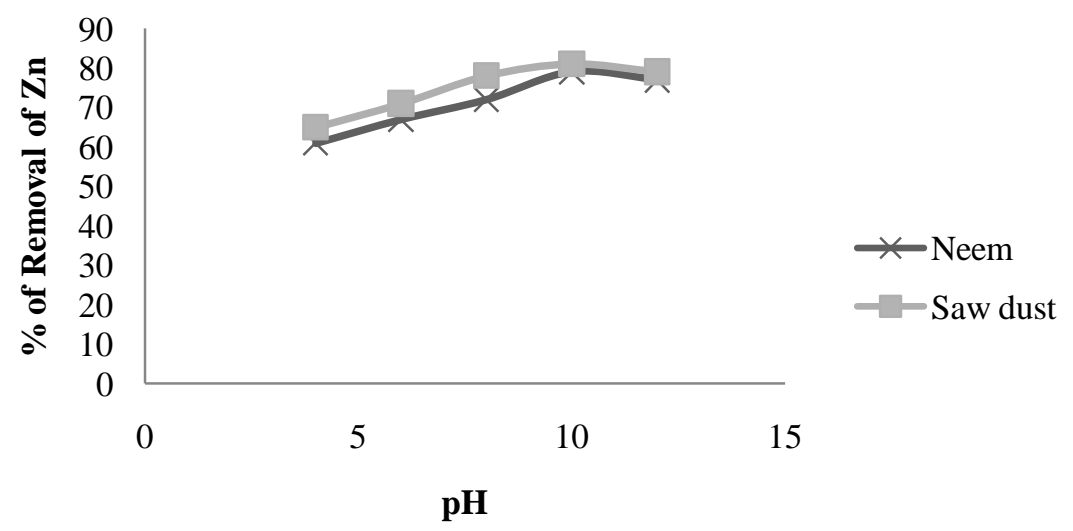

Fig. 3 Effect of $\mathrm{pH}$ of two adsorbents

From the graph shown in Fig.3 it was observed that neem powder and saw dust almost same result in \% removal of zinc at different $\mathrm{pH}$ levels of adsorbate solution. But the neem powder showed better result than saw dust to some extent. The variation in the sorption capacity between the various adsorbents could be related to the nature and concentration of surface groups responsible for interaction with the metal ions.

\section{CONCLUSION}

The utilization of waste material such as saw dust and neem powder for the removal of zinc from industrial waste water streams was investigated. The following conclusions could be drawn based on investigation. Neem powder and Saw dust are found to be better adsorbents for the removal of zinc compared to other low cost and commercially available adsorbents. The maximum adsorption of zinc for saw dust (72\%) and neem powder $(82.2 \%)$ was observed at $\mathrm{pH} 12.24$ respectively. Langmuir isotherm better fitted the experimental data since the correlation coefficients for Langmuir isotherm was higher than the Freundlich isotherms. After fitted the data, the Langmuir constant (n) was lower than the Freundlich constant.

The present adsorbents such as saw dust and neem powder are used at an industrial scale to remove zinc ions from the effluents before discharging in to the water bodies. With the increase of adsorbent amount the percentage removal of zinc increases and the adsorption capacity of saw dust to adsorb zinc decreases because of availability of more unsaturated adsorption sites. Most of the electroplating effluents contain chromium as one of the contaminant, which can be removed in a cost effective and efficient manner by these adsorbents Neem biosorbent exhibited highest zinc removal efficiency $82.2 \%$ at $\mathrm{pH}$ of 12.24 , initial zinc concentration of $1000(\mathrm{mg} / \mathrm{l})$, contact time of $90 \mathrm{~min}$, adsorbent dosage of $5 \mathrm{~g} / 100 \mathrm{ml}$ and maintaining temperature of $307 \mathrm{~K}$. Zinc removal for a given adsorbent increases with time, attaining equilibrium within $90 \mathrm{~min}$.

The optimum sorbent dosage was found at $5 \mathrm{~g} / 1001$ for both neem powder and saw dust. Enhanced adsorption was obtained at $150 \mathrm{~min}$. It could be seen that the neem powder is more efficient in removing zinc from effluent streams as compared to saw dust. The Langmuir adsorption is found to be more suitable than freundlich isotherm. As the adsorbents used in this work are natural, they are economically cheap and eco-friendly. 


\section{REFERENCES}

1. N.Ahalya, R.D.Kanamadi and T.V.Ramachandra,"Removal of hexavalent Cr using coffee husk."

2. A.K.Bhattacharya, S.N.Mandal and S.K.Das,"Removal of Cr (VI) from aqueous solutions by adsorption onto low cost non-conventional adsorbents" (2006).

3. M.Dakky, M.Khamis, A.Manassra and M.Mer'eb,"Selective adsorption of Cr (VI) in industrial waste water using low cost abundantly available adsorbents" (2002).

4. Haluk Aydin, Yasemin Bulut and Cigdem Yerlikaya,"Removal of copper (II) from aqueous solutions by adsorption onto low-cost adsorbents" (2007).

5. G.D.Matos and M.A.Z Arruda,"Vermicompost as natural adsorbent for removing metal ions from laboratory effluents" (2002).

6. Siama Q.Memon, Najma Memon, S.W.Shah, M.Y.Khuhawar and M.I.Bhanger," Sawdust-A green and economical sorbents for the removal of cadmium (II) ions" (2006).

7. Nasim Ahmad Khan, Md.Ghazaly Shabaan and Mohd Hasruddin Hassan, "Removal of heavy metals using an inexpensive adsorbent" (2003).

8. R.P.Singh,R.C.Vaishya and S.C.Prasad,"A Study of removal of hexavalent chromium by adsorption on saw dust."

9. M.Rao, A.V.Parwate and V.P Deshpande,"Removal of heavy metals by adsorption process using bagasse.”.

10. M.Rao, A.V.Parwate and A.G.Bhole, "Removal of Cr (VI) and Ni (II) from aqueous solutions using bagasse and fly ash."

11. Suresh Gupta and B.V. Babu,"Removal of Cr (VI) from waste water using fly ash as an adsorbent."

12. Suresh Gupta and B.V. Babu, "Adsorption of Chromium (VI) by a low-cost adsorbent prepared from tamarind seeds."

13. Suresh Gupta and B.V. Babu, "Removal of toxic metal Cr(VI) from industrial waste water using saw dust as adsorbent:equilibrium,kinetics and regeneration studies".

14. Thomas Anish Johson, Niveta Jain,H.C Joshi and Shiv Prasad, "Agricultural and agroprocessing wastes as low cost adsorbents for metal removal from waste water"(2008).

15. Vikrant Sarin and K.K. Pant," Removal of chromium from industrial waste by using eucalyptus bark" (2005).

16. APHA, 1992 standard methods for the examination of water and waste water, $18^{\text {th }}$ ed. APHA, Washington, Dc.

17. V.Vinodini and N.Das," Relevant approach to assess the performance of saw dust as a adsorbent of chromium (VI) ions from aqueous solutions". 